\title{
Religião, sacrifício e violência
}

\author{
Paul Clemens Cavalin*
}

Transcrição traduzida ao português de sua palestra em inglês, com o mesmo título, para a aula magna do PPG em Ciência da Religiáo da PUC-SP, ocorrida em 7 de outubro de 2021. Por se tratar de uma palestra, não há citaçóes e outros elementos típicos da língua acadêmica escrita. Transcrição e tradução por Fábio L. Stern.

Existe uma ligação estreita entre os temas "religião" e "sacrifício". Na maioria das definiçóes, sacrifício, ao contrário das oferendas em geral, exige que o objeto, arma, animal ou pessoa ofertado seja destruído, o que, no caso de animais, geralmente significa que sua garganta seja cortada e seu corpo seja assado ou queimado por inteiro, ou levado ao deserto para morrer, como o bode expiatório do judaísmo do Antigo Testamento. A categoria oferendas, por outro lado, abrange também o incenso que sobe aos céus, a dispersáo de pétalas de rosa, libaçóes de leite, água e vinho. O sacrifício gira em torno do derramamento de sangue, a força vital do bode, ovelha ou touro doada em partes ou no todo à divindade.

No judaísmo ou na velha religião nórdica, o sacrifício prototípico é o de um animal abatido ritualisticamente seguido de um banquete festivo ou de uma simples refeição. A espantosa semelhança com o assassinato de um ser humano é agravada quando a vítima animal cumpre um papel de vítima na relação com o sacrificador que patrocina o sacrifício - segundo a taxonomia sacrifical de Henri Hubert e Marcel Mauss. A vítima, então, redime o sacrifício da morte.

Para o cientista da religião, é conveniente definir sacrifício como um subtipo de oferenda, com as ofertas votivas como seu extremo contraste, presentes aos deuses que se tornam deles e são colocados em solo sagrado (p. ex., dentro de um templo). Apesar das diferenças, o sacrifício segue a estrutura básica de uma oferenda que estabelece e mantém a comunicação com o mundo oculto dos deuses. A maioria dos sacrifícios animais é rodeada por oferendas sem sangue (p.ex., incensos, fluidos e substâncias vegetais).

Implícita na maioria dos discursos sobre religião e violência há uma dimensão política em que a violência é vista como algo a ser cerceado para manter ou recuperar a coexistência pacífica entre grupos e identidades antagônicos. Porém, o sacrifício não é o simples ato de matar ou um assassinato ritual, mas uma forma de sacralizar, regular e transformar a violência. É verdade que, por vezes, esse processo é destrutivo e contrário

\footnotetext{
* Professor da Nord universitet (Noruega). Doutor em Religionsvetenskap (Ciência da Religião) (Göteborgs universitet, Suécia). ORCID: 0000-0002-5836-3539 - contato: paul.c.cavallin@nord.no
} 
aos direitos e obrigações universais. Contudo, o sacrifício, aliado a uma boa razão, realça a questâo da violência necessária e sua legitimidade.

O sacrifício está intimamente ligado a questôes éticas centrais. O mecanismo sacrifical é uma forma de destruiçáo criativa. Sacrifica-se algo menor por um objetivo maior, reforçando uma hierarquia de valores, prestígio e poder. Um animal é sacrificado para agradar a um deus, mas também para fornecer alimento a um grupo de pessoas. $\mathrm{O}$ rito de sacrifício geralmente envolve um sentimento de culpa e atos para preparar as espécies animais. Reconhece obrigaçóes e demonstra gratidão (p. ex., devolvendo o primogênito e a primeira colheita aos deuses).

O oposto do sacrifício é a manipulação industrial de animais e a indústria bélica moderna desencantada. Sem o espaço sagrado e o tempo sagrado do sacrifício, sem o reconhecimento ético de que o sacrifício real é o de si próprio, para o qual se poderia propor substitutos, a ética dá lugar a uma racionalidade instrumental sem fronteiras que calcula cruelmente os métodos mais eficientes de se matar. A apoteose dessa mentalidade é, evidentemente, as bombas nucleares e de hidrogênio, a morte que destrói mundos.

Analisar as tradiçóes de sacrifício pela perspectiva da violência leva o pesquisador a refletir sobre a modernidade e sobre o próprio contexto da iniciativa acadêmica. A questão é se a era moderna transcendeu, de fato, a longa e violenta pré-história da humanidade ou se ela está lá, sob a superfície da civilização tecnológica, um nível mais profundo de ferocidade animal que foi moldada por milênios de caça e guerras tribais e que foi a força motriz dos massivos cultos de sacrifício das culturas agrárias, mas também, como no caso dos astecas, o princípio por trás dos sacrifícios em larga escala de homens e mulheres. São as guerras modernas apenas a manifestação mais recente desse princípio?

A Primeira Guerra Mundial foi para muitos um despertar brutal para as realidades do princípio sacrifical. O progresso científico sem precedentes do séc. XIX e o otimismo que o acompanhou morreram nas trincheiras do norte da França. O hediondo holocausto dos judeus, apenas três décadas depois, reforçou a visão da crueldade ilimitada da qual o ser humano é capaz. Nenhum sacrifício é grande ou extremo demais.

Tal preocupação com a natureza destrutiva do humano e as perspectivas precárias da civilizaçáo moderna animou tanto René Girard quanto Walter Burkert a publicar livros sobre violência e sacrifício na década de 1970. O mecanismo do bode expiatório, frisado por Girard, e a ritualização da caça, com a necessária matança da presa que depois se transforma em vítima do sacrifício, são similares, mas diferentes. Girard passou a ver o cristianismo e a morte da vítima inocente Jesus como algo que transcendia o mecanismo violento do bode expiatório e do sacrifício. Burkert, por outro lado, viu apenas tentativas diferentes de esconder a natureza violenta do ser humano com uma camada fina de civilização, o que talvez levaria a resultados trágicos no fim.

Assim, a reflexão sobre a natureza violenta ou basicamente pacífica do ser humano é também uma reflexão sobre as perspectivas da modernidade, a grande tentativa de criar uma civilização sem a ajuda dos deuses e da graça divina. Porém, para isso se supóe que a humanidade é basicamente boa, que no fundo as pessoas são governadas por instintos e princípios construtivos e socialmente benéficos. Se a desordem humana não vir apenas de fatores externos, mas proceder de uma perturbação ou corrupção mais 
profunda, então ela destaca uma natureza trágica da sociedade secular moderna que, em última análise, jaz na bondade básica da natureza humana. A razão pura utilizada com motivos decadentes produz instituiçóes como Auschwitz, o Gulag e estados totalitários de vigilância, como a China atual. Teorias antropológicas e sociológicas sondam as causas inconscientes da violência sacrifical e seus fenômenos análogos nas sociedades modernas, como soldados que se sacrificam pela nação.

Para um religioso, entretanto, o sacrifício só faz sentido quando em seu próprio mundo religioso. Pode-se investigar, portanto, o significado e papel dos sacrifícios, o sacrifício como ideia, uma metáfora, considerando também o asceticismo e a autonegação em geral. É um caso central o papel da vontade de Abrão de sacrificar seu filho Isaac ou Ishmael como ordenado por Deus no judaísmo, cristianismo ou islá. De fato, o cristianismo tradicional é incompreensível quando o sacrifício de Jesus na cruz é negligenciado como aquele que cumpre o que o sacrifício de Isaac não pôde. $\mathrm{O}$ foco de tais estudos é, então, a mente religiosa, o mundo criado pela secularização ritual, por poderosas narrativas de criação, e não um foco no programa precário e ético da modernidade liberal.

Nessa apresentação, não tenho tempo para fazer uma exegese completa dos escritos de Burkert e Girard, os pesquisadores mais conhecidos da violência sacrifical, ou delinear os processos de secularização da mente religiosa. Quero focar na natureza das reflexôes acadêmicas sobre sacrifício e violência, especialmente porque isso diz respeito à natureza humana. Se nós, nessa palestra de pós-graduação, discutirmos a ritualização das oferendas de primícias, podemos situá-las em um contexto agrário pré-moderno adequadamente distante do cenário urbano típico de uma universidade. Ou quando analisamos o martírio jihad e atos de terrorismo fundados em uma ideologia de sacrifício, vemos a nós mesmos como espectadores do fanatismo religioso que, por definição, está ausente das salas das universidades, que considera os direitos humanos como um valor fundamental.

Mas quando se associa o sacrifício à violência, a questão da natureza humana e da civilização vem à tona, já que obviamente o séc. XX não foi o mais pacífico. De fato, a ciência e a tecnologia colocam a sobrevivência da raça humana em xeque. Não podemos desconsiderar que, ao ligar o sacrifício à violência, também minamos a clara distinção iluminista das formas religiosas pré-modernas de pensamento e formaçôes sociais e os modos de pensamento e vida social que fluem da razão humana emancipada. Ainda somos violentos. Ainda sacrificamos nossos inimigos. Enquanto escrevo isso, o projeto de democracia liberal no Afeganistáo está desmoronando num intervalo de apenas alguns dias. Ainda nos lembramos das dramáticas execuçóes on-line realizadas pela EIIL no Iraque e no Norte da África. E então, do aniversário do 11 de setembro.

A reflexão acadêmica sobre sacrifício implica um autoescrutínio. A violência sacrifical é um espelho no qual nos vemos mais ou menos nítidos e devemos fazer um julgamento ético sobre nossos atos. Mesmo se adotarmos a posição de muitos cientistas da religião, uma postura pós-metafísica de neutralidade e náo confessionalidade, e apenas relatar a verdade não envernizada da violência sacrifical, não podemos esquecer que nossa proposta de verdades sobre a condição humana também estabelece os parâmetros para as possíveis formas de civilização. 


\section{Paul Clemens Cavalin}

Para Émile Durkheim, o sociólogo mais proeminente do início do séc. XX e um homem que estudou proeminentemente a religião, essa interligação entre vida cotidiana e academia teve consequências trágicas. Em seus escritos, ele especula e até promove uma futura religião secular que tem a aura sagrada das religióes metafísicas tradicionais. Para ele, os deuses são meros símbolos do próprio grupo social. Portanto, os atos religiosos, incluindo o sacrifício, são voltados à própria sociedade, que é o verdadeiro Deus. Para Durkheim, o individualismo, que é o liberalismo, não é apenas uma religião entre muitas, mas o único sistema de crenças que pode assegurar a unidade moral do país. Ele até afirma que é por isso que o homem se tornou Deus para si próprio e não pode mais se voltar aos outros deuses sem ser falso consigo mesmo.

Em 21 de fevereiro de 1916, a batalha de Verdun começou simbolicamente com uma granada de artilharia alemá na catedral do séc. X. Começou-se um massacre sem sentido que, no fim, levou a 300.000 mortos e 500.000 feridos. Quatro dias depois, o único filho de Durkheim, Andre, foi declarado morto. Ele tinha sido baleado em dezembro de 1915, na frente búlgara, e morreu mais tarde pelo ferimento. Durkheim chorou, mas se certificou de se ocupar trabalhando. Ele escreveu a um amigo: "Claro que sei que as religióes estão aí e que suas práticas são ricas em experiência inconsciente e sabedoria acumulada, mas sua sabedoria é grosseira, não empírica. Nada que se assemelhe a práticas rituais me foi útil ou me parece eficaz". A nação tinha exigido seu sacrifício: seu único filho. E a nova religião, o culto da humanidade, não pôde ajudá-lo.

Durkheim nunca se recuperou, ficou cada vez mais magro e febril. No final de 1916, quando deixava uma reuniáo do comitê do esforço de guerra da França, ele teve um derrame. Ele sobreviveu, mas morreu no ano seguinte. E depois de mais um ano, a guerra terminou.

Nessa palestra, conectamos um cientista sueco que vive e trabalha na Noruega com um curso de pós-graduação em São Paulo, Brasil. Fomos afetados por uma pandemia global que matou centenas de milhares de pessoas e que fechou nossa sociedade de uma maneira inimaginável há apenas alguns anos, quando a globalização tinha uma aura de irresistibilidade. Meu ponto é que quando começamos a refletir sobre sacrifício e violência, estamos também refletindo sobre nossa humanidade comum e a situação atual. É trágico que, apesar das boas intençóes, dos discursos floridos e tratados assinados, tenhamos que sacrificar. Impulsionados pelo instinto de sobrevivência, intençóes justas ou puro egoísmo, derramamos sangue. A paz é apenas um momento fugaz. Com a chegada da crise, as paixôes vêm à tona.

A questão central do estudo do sacrifício nesse modo autorreflexivo é se somos capazes de transcender nossa natureza violenta. Supondo que o sacrifício ritual não seja só um reflexo da violência necessária, como a caça ou o abate animal para a alimentação, mas talvez um mecanismo para transformar princípios destrutivos instintivos. E num segundo passo, o autossacrifício voluntário, como encontrado nos movimentos ascéticos, questiona maximizar lucros, prazeres e poderes. Logo, o sacrifício é crucial para qualquer postura ética que rejeite o egoísmo, mas também pode ser usado para a violência, como no terrorismo.

Quanto a Durkheim, Girard e Burkert, nossas teorias de sacrifício têm consequências para nossa vida. Um sacrifício é um ato de comunicação com nossos deuses; o deus 
transcendente cristão, um dos muitos deuses hindus, ou um dos "deuses modernos", como a nação. $\mathrm{O}$ que é inferior é sacrificado pelo que é superior. $\mathrm{O}$ sacrifício, então, não apenas cobra eticamente o indivíduo, como também o grupo social. Se o princípio sacrifical é, de alguma forma, parte de nossa natureza humana moldada ao longo de milênios, então não pode simplesmente ser negado como parte de estágios anteriores à civilização, como algo que superamos, mas sim temos de nos conformar com suas demandas éticas. Em certo sentido, somos como Durkheim e Abrão, destinados a viver sob a terrível perspectiva de um deus que nos obriga a sacrificar nossa posse mais valiosa, neste caso, nosso filho, nosso futuro.

Mesmo uma teoria acadêmica do sacrifício estabelece o cenário para uma resposta de se e como o princípio sacrifical pode ser sublimado, transcendido, ou se estamos simplesmente desamparados diante de seu poder. Do ritual, passando pela ética, até a civilização, o sacrifício é um fio vermelho da história humana. 